\title{
Alternate Strip Clearcutting in Upland Black Spruce IV. Projected Nutrient Removals Associated with Harvesting
}

\author{
by
}

Neil W. Foster and lan K. Morrison ${ }^{1}$

\section{Abstract}

Nutrient removals associated with conventional, full-tree, and whole-tree harvesting on 100-year rotations in an upland boreal black spruce stand in northern Ontario were estimated. Conventional (stems only) logging would remove $219 \mathrm{kgha}^{-1}$ of $\mathrm{Ca}, 62$ of $\mathrm{N}$, 36 of $\mathrm{K}, 18$ of $\mathrm{Mg}$ and 9 of $\mathrm{P}$ from the site. Increased utilization of phytomass during full-tree harvesting, in comparison with conventional logging, could result in as much as a $400 \%$ increase in $\mathrm{N}$ removal and a $60 \%$ increase in $\mathrm{Ca}$ removal. Estimates of projected $\mathrm{N}$ and $\mathrm{K}$ removals by full-tree harvesting may be conservative, relative to those in other black spruce stands because of the low foliar mass of this forest. The forest floor contained $51 \%$ to $72 \%$ of the soil's reserves of nutrients, except for $P$, within the effective rooting zone. Postharvesting site preparation methods should be restricted to those that ensure that forest floor nutrient reserves are retained on site.

\section{Résumé}

On a estimé l'exportation des éléments nutritifs liée à l'exploitation classique, à l'exploitation par arbres entiers et à l'exploitation de toute la phytomasse, sur une révolution de 100 ans, dans un peuplement d'épinettes noires de type boréal des hautes terres du nord de l'Ontario. L'exploitation classique (fûts seulement) s'accompagnerait d'une exportation de $219 \mathrm{~kg}$ de $\mathrm{Ca}$, de $62 \mathrm{~kg}$ de $\mathrm{N}$, de $36 \mathrm{~kg}$ de $\mathrm{K}$, de $18 \mathrm{~kg}$ de $\mathrm{Mg}$ et de $9 \mathrm{~kg}$ de $\mathrm{P}$ à l'hectare. L'utilisation accrue de la phytomasse durant l'exploitation par arbres entiers provoquerait, par rapport à l'exploitation traditionnelle, une augmentation de jusqu'à $400 \%$ de l'exportation de $\mathrm{N}$ et de $60 \%$ de l'exportation de $\mathrm{Ca}$. L'estimation de l'exportation prévue de $\mathrm{N}$ et de $\mathrm{K}$, par l'exploitation par arbres entiers peut être prudente, si on la compare à celle d'autres peuplements d'épinettes noires, à cause de la faible masse foliaire de ce type de forêt. La couverture morte contient de 51 à $72 \%$ des réserves du sol en éléments nutritifs, sauf $P$, à l'intérieur de la zone utile d'enracinement. Les méthodes de préparation du sol après l'exploitation devraient se limiter à celles qui font en sorte que les réserves nutritives de la couverture morte restent sur place.

\section{Introduction}

In considering the effects of harvesting on forest ecosystems, a serious concern is the increased quantities of plant nutrients that are removed from the site because of the tendency toward more intensive management, with its fuller utilization of phytomass and shorter rotations. Knowledge of the quantitites of nutrients contained in portions of the forest phytomass permits predicting nutrient removals associated with different degrees of utilization. This information, in turn, can be used in selecting forest management options for establishing and tending the next forest. For example, species with low nutrient demands might be chosen for sites on which nutrients are limited, or sites where fertilization may be needed to maintain or improve forest productivity. The objective of this

Canadian Forestry Services, Great Lakes Forestry Centre, P.O. Box 490, Sault Ste. Marie, Ontario P6A 5 M7. study was to quantify the phytomass and nutrient content of a mature upland black spruce (Picea mariana [Mill.] B.S.P.) stand on a shallow (0 to $85 \mathrm{~cm}$ deep) acid till. Potential nutrient removals associated with conventional, full-tree, and wholetree harvesting on 100-year rotations are estimated and discussed.

\section{Site Description}

The study area was near Lake Nipigon in northern Ontario (lat. $49^{\circ} 30^{\prime} \mathrm{N}$; long $87^{\circ} 50^{\prime} \mathrm{W}$ ), within the Central Plateau Section (B.8) of the Boreal Forest Region (Rowe 1972). The experimental area was located on thin deposits of stony, silty, morainal till over compact, sandy, basal till and/or granitic bedrock. The soil has an Orthic Humo-Ferric Podzol profile (Canada Soil Survey Committee 1978).

Soid depth was highly variable, ranging from humusover-bedrock to a maximum of $85 \mathrm{~cm}$ of till over bedrock, and generally increased in depth from the crest to the lower slope position. The average effective rooting depth in the mineral 
soil was $13 \mathrm{~cm}$ in the crest position and up to 21 and $23 \mathrm{~cm}$ in the upper and lower slope positions, respectively. Sinker roots with many branches and fine roots $(<1 \mathrm{~mm})$ were present in abundance throughout the ablation till. The density of rooting was far less in the compacted, infertile, sandy basal till in the deeper soil deposits. Stoniness was about $40 \%$ throughout the soil profile.

The stand examined occupied a south-facing slope extending $300 \mathrm{~m}$, with the crest elevated $10 \mathrm{~m}$ above the drainageway. The main stand consisted of ca 110-year-old black spruce, contributing ca $87 \%$ of the total basal area (BA), with jack pine (Pinus banksiana Lamb.) accounting for $10 \%$, and balsam fir (Abies balsamea [L.] Mill.), trembling aspen (Populus tremuloides Michx.), and white birch (Betula papyrifera Marsh.) combined accounting for the remaining $3 \%$. Mean dominant height, measured on sample plots, was $19.6 \mathrm{~m}$; mean diameter at breast height (DBH), averaged over all species and all trees with measurable diameter, was $14.8 \mathrm{~cm}$ (ranging up to $31.3 \mathrm{~cm}$ for black spruce, and up to $31.5 \mathrm{~cm}$ for jack pine). Mean BA was $23.0 \mathrm{~m}^{2} / \mathrm{ha}$. There were ca 1200 stems/ha. Total standing volume was $178.3 \mathrm{~m}^{3} / \mathrm{ha}$. Merchantable standing volume was $164.6 \mathrm{~m}^{3} / \mathrm{ha}$. Additional details of vegetation and site are contained in Tables 1 and 2 and in Jeglum (1980).

\section{Methods}

Twelve contemporary 0.10 -ha rectangular sample plots were established in adjacent first-cut leave strips, three each in the crest, upper slope, lower slope and drainageway. The $\mathrm{DBH}$ of all trees was tallied by species during the summer of 1977. Dry weights of 25 mature and 14 understory black spruce trees, of 10 such jack pine and of 24 balsam fir trees were determined. The jack pine data set was augmented by data from mature trees elsewhere in northern Ontario. A method adapted from Hegyi (1972), in combination with stand tables from the temporary sample plots, was used to calculate dry weights per hectare, by components.

Samples of foliage, cones, live branches, dead branches, stem bark, stem wood, and wood and bark material from stumps and roots were collected from a total of 88 trees. These trees were distributed in equal numbers covering the range of tree sizes found in the 12 sample plots during the late summer of 1978 . Samples were oven dried at $70^{\circ} \mathrm{C}$ until they reached constant weight, were ground, and were analyzed chemically according to Morrison (1985). Contents of N, P, K $\mathrm{Ca}$, and $\mathrm{Mg}$ were calculated on a plot-by-plot basis by mean concentrations and plot dry weight. Data were expressed as the mean of 12 plots.

Dry weights of ground vegetation and forest floor horizons were estimated on the crest in late July from $1000.09-\mathrm{m}^{2}$ and $800.02-m^{2}$ randomly selected subplots, respectively. Litterfall was collected six times a year for three years from $200.25-\mathrm{m}^{2}$ traps within a 0.06 -ha subplot on the crest. Soil samples were collected from 10 pits within each of three 0.25 -ha plots, one on the crest, one on the upper slope and one on the lower slope. Soil pits were dug to bedrock. Each major horizon encountered was described and sampled. Soil was analyzed for the following: total $\mathrm{N}$ by semimicro-Kjeldahl digestion, total $\mathrm{P}$ after acid digestion, and exchangeable $\mathrm{K}, \mathrm{Ca}$ and $\mathrm{Mg}$ by atomic absorption after extraction with $1 \mathrm{~N}$ ammonium acetate buffered at $\mathrm{pH}$ 7.0. Potential mineralized $\mathrm{N}$ was estimated as the difference in $\mathrm{N}$ extracted by $2 \mathrm{M} \mathrm{KCl}$ from soil at the

Table 1. Physical properties, $\mathrm{pH}$ and CEC of the soil. Average values \pm SD.

\begin{tabular}{|c|c|c|c|c|c|c|c|c|}
\hline Horizon & $\begin{array}{l}\text { Depth } \\
\text { (cm) }\end{array}$ & $\begin{array}{c}\text { Bulk } \\
\text { density } \\
\left(\mathrm{g} \mathrm{cm}^{-3}\right)\end{array}$ & $\begin{array}{l}\text { Percent of } \\
\text { weight in } \\
\text { materials } \\
>2 \mathrm{~mm}\end{array}$ & Texture & $\begin{array}{c}\text { Organic } \\
\text { matter } \\
(\%)\end{array}$ & $\begin{array}{c}\text { CEC }^{\mathbf{C}^{2}} \\
(+) \mathbf{k g}\end{array}$ & $\mathrm{pH}^{\mathrm{b}}$ & $\mathbf{n}$ \\
\hline F & $10-2$ & 0.1 & - & - & $90.5 \pm 1.3$ & $104.1 \pm 8.2$ & 3.0 & 15 \\
\hline $\mathrm{H}$ & $2-0$ & 0.4 & - & - & $49.0 \pm 9.1$ & $99.1 \pm 9.7$ & 2.8 & 15 \\
\hline $\mathrm{Ae}$ & $0-2$ & 1.0 & $42 \pm 25$ & silt loam & $4.3 \pm 1.8$ & $16.2 \pm 4.4$ & 3.3 & 20 \\
\hline $\mathrm{Bf}$ & $2-7$ & 0.9 & $43 \pm 24$ & loam & $5.1 \pm 2.0$ & $19.3 \pm 6.5$ & 3.7 & 22 \\
\hline $\mathrm{Bf}_{2}^{1}$ & 7-19 & 1.2 & $43 \pm 25$ & loam & $2.8 \pm 1.6$ & $11.9 \pm 3.4$ & 3.9 & 24 \\
\hline$B_{m}^{2}$ & $19-20$ & 1.1 & $37 \pm 26$ & loam & $1.7 \pm 0.8$ & $7.4 \pm 4.2$ & 4.3 & 5 \\
\hline$I I C$ & $20-32$ & 1.5 & $41 \pm 27$ & sandy loam & $1.1 \pm 0.5$ & $6.3 \pm 1.9$ & 4.3 & 18 \\
\hline
\end{tabular}

${ }^{a} \mathrm{NH}_{4} \mathrm{OACc}(\mathrm{pH} 7.0)$

${ }^{\circ} 0.01 \mathrm{M} \mathrm{Ca} \mathrm{Cl}_{2}$

Table 2. The dry matter and nutrient content of black spruce dominated forest.

\begin{tabular}{|c|c|c|c|c|c|c|c|c|c|c|c|}
\hline \multirow[b]{2}{*}{ Age } & \multirow{2}{*}{$\begin{array}{c}\text { Basal } \\
\text { area }\end{array}$} & \multirow[b]{2}{*}{ Site } & \multicolumn{3}{|c|}{ Phytomass } & \multicolumn{5}{|c|}{ Standing crop (aboveground) } & \multirow[b]{2}{*}{ Reference } \\
\hline & & & Aboveground & Crown & Foliage & $\mathbf{N}$ & $\mathbf{P}$ & $\mathbf{K}$ & $\mathrm{Ca}$ & Mg & \\
\hline years & $\mathrm{m}^{2} \mathrm{ha}^{-1}$ & & \multicolumn{3}{|c|}{$\ldots \ldots \ldots \mathrm{tha}^{-1} \ldots \ldots \ldots$} & \multicolumn{5}{|c|}{$\ldots \ldots \mathrm{kg} \mathrm{ha}^{-1} \ldots \ldots$} & \\
\hline 65 & 42 & SL till ${ }^{a}$ & 107 & 18.6 & 8.3 & 167 & 42 & 84 & 276 & 27 & Weetman and Webber (1972) \\
\hline 75 & 28 & - & 113 & - & - & 240 & 30 & 112 & 314 & 33 & Freedman and Duinker (1985) \\
\hline 95 & 25 & SiL loess ${ }^{a}$ & 50 & 13.5 & $5 . \overline{6}$ & 123 & 14 & 57 & 285 & 27 & Van Cleve et al. 1983 \\
\hline 48 & 33 & sand & 141 & 35.8 & 15.9 & 482 & 26 & 308 & 370 & 44 & Gordon (1983) \\
\hline 108 & 40 & peat & 161 & 40.4 & 17.7 & 547 & 29 & 350 & 414 & 50 & " \\
\hline 110 & 23 & $\mathrm{~L} \mathrm{till}^{\mathrm{a}}$ & 142 & 35.2 & 9.1 & 234 & 18 & 122 & 334 & 42 & Present study \\
\hline 126 & 32 & SL till ${ }^{a}$ & 138 & 22.7 & 7.6 & 536 & 65 & 141 & 1024 & 66 & Timmer et al. $1983^{\circ}$ \\
\hline 126 & 49 & SL till & 325 & 39.1 & 12.6 & 897 & 108 & 220 & 1696 & 106 & \\
\hline
\end{tabular}

a $\mathrm{SL}=$ sandy loam, $\mathrm{L}=$ loamy, $\mathrm{SiL}=$ silty loam.

'Values represent nutrient exports associated with full-tree harvesting. 
beginning and end of a 12-week incubation at constant $33 \mathrm{kPa}$ moisture and $20^{\circ} \mathrm{C}$. Soil nutrient contents were computed by horizons on the basis of nutrient concentrations, depth, and bulk density and stoniness.

\section{Results}

The largest nutrient pools within the forest vegetation component of the ecosystem were for $\mathrm{N}$ in the foliage, $\mathrm{K}$ in the live branches, $\mathrm{P}$ and $\mathrm{Mg}$ in the wood and $\mathrm{Ca}$ in the bark (Table 3). An additional $33 \%$ and $43 \%$ more phytomass could be harvested from this forest by using full-tree and whole-tree havesting, respectively, rather than conventional methods (Table 4). This gain would result in a $400 \%$ increase in $\mathrm{N}$ removal from the site, a $300 \%$ increase in $\mathrm{K}$, a $200 \%$ increase in $\mathrm{P}$ and $\mathrm{Mg}$ and a $60 \%$ increase in $\mathrm{Ca}$. Whole-tree harvesting would more than double that component of soil acidification associated with cation uptake through removal of bases in vegetation (Table 5).

The forest vegetation contained $7 \%$ of the total $\mathrm{N}$ at the site and $3 \%$ of the total P (Table 6 ). There was more $\mathrm{K}$ and $\mathrm{Ca}$ in the vegetation than on the cation exchange sites in the soil. The nutrient content of the forest floor exceeded that of the ablation till for all nutrients except $P$ (Table 6 ). The vegetation and forest floor together contained $62 \%$ of the N, but only $27 \%$ of the $P$, at the site.

\section{Discussion}

\section{Vegetation Nutrient Contents}

The results from this study apply only to a limited, but very representative, area of shallow podzolic soils supporting upland black spruce near Nipigon, Ontario, because nutrient accumulation is site and species specific. This site, with a medium textured till, supported a very productive but considerably understocked black spruce stand. Conventional shortwood or tree-length harvesting (where stems only are removed) would result in considerable $\mathrm{Ca}$ removal from this site because of the amount of $\mathrm{Ca}$ within the bark and wood (Table 3). The removal of nutrient-rich foliage and branches, however, would contribute to a much greater loss of $\mathrm{N}$ and $\mathrm{K}$ and, to a lesser extent, $\mathrm{P}$ and $\mathrm{Mg}$, with full-tree harvesting (where the entire above ground portion is removed) than with conventional practice. For example, full-tree logging would remove approximately $172 \mathrm{~kg}$ more $\mathrm{N}$ per ha from this site than would conventional harvesting. The additional removal of nutrients associated with extracting and removing the stump and roots along with the above ground components (often referred to as whole-tree as opposed to "full-tree" harvesting) would be small. The results of the vegetation assessment indicate that full-tree harvesting of this spruce stand would exert a considerably larger nutrient drain on soil reserves than would conventional (stems only) logging.

Nutrient contents in this stand in general, and $\mathrm{N}$ and $\mathrm{P}$ accumulations specifically, were quite modest in comparison with those reported previously for black spruce (Table 2). The black spruce stands were quite variable in their nutrient content and hence in their potential for nutrient removal by harvesting. The variability is related to differences in stand productivity which are determined by stand age, environmental factors, site fertility and genetic variation within black spruce populations. In part, the low nutrient content of this stand reflects the low stand density and, particularly, the very low foliar mass which was well below that of some stands of equal crown weight (Table 2). Consequently, one might expect an even greater $\mathrm{N}$ and $\mathrm{K}$ drain with full- or whole-tree harvesting from a site with a greater foliar mass, and this was observed (Table 2).

\section{Soil Nutrient Reserves}

From a nutritional point of view it is the nutrient content of the humus and surface mineral horizons that is critical for black spruce because fine roots are commonly most abundant there, and in some cases are restricted largely to these horizons. Forest floor horizons, in these shallow soils, contained a large proportion ( $\mathrm{K} 72 \%$, Ca $68 \%$, N $59 \%$, Mg 51\%, P 23\%) of the nutrient capital of the soil (Table 6). Moreover, organic horizons protect the mineral soil from the impact of rainfall, so that surface runoff and soil erosion are reduced. Slash removal exposes the ground surface to excessive heating and drying.

It is generally considered necessary to expose mineral soil to favor natural regeneration of black spruce on upland sites. Exposure may be accomplished by fire or scarification. Of the two, fire will have particularly serious consequences, in that much of the $\mathrm{N}$ reserve in the slash and humus could be volatilized into the atmosphere and other plant nutrients could be subject to erosion by wind and water. Post-harvesting treatments to encourage regeneration that result in removal of the nutrient capital of the humus should be avoided on shallow till soils. A light scarification, i.e., one in which organic materials are mixed with the surface mineral soil, is preferable to treatments that remove slash and humus. Incorporation of organic matter into the soil also increases the cation exchange capacity of the soil and hence the capacity of the soil for nutrient retention.

Post-harvest regeneration can benefit from the nutrients in slash and in the forest floor that would not have been

Table 3. Distribution $(x \pm S D)$ of phytomass and nutrients in a 110-year-old black spruce forest.

\begin{tabular}{|c|c|c|c|c|c|c|}
\hline \multirow[b]{2}{*}{ Component } & \multirow{2}{*}{$\begin{array}{c}\text { Phytomass } \\
\left(\mathbf{k g ~ h a}^{-1}\right)\end{array}$} & \multicolumn{5}{|c|}{ Stand content ( $\mathrm{kg} \mathrm{ha}^{-1}$ ) } \\
\hline & & \multirow{2}{*}{$\frac{\mathbf{N}}{80 \pm 19}$} & \multirow{2}{*}{$\frac{\mathbf{P}}{5.7 \pm 1.4}$} & $\mathbf{K}$ & $\mathrm{Ca}$ & Mg \\
\hline Foliage & $9100 \pm 2200$ & & & $33 \pm 8$ & $54 \pm 13$ & $8.8 \pm 2.1$ \\
\hline Cones & $3600 \pm 1000$ & $11 \pm 3$ & $1.5 \pm 0.4$ & $3 \pm 0.8$ & $3 \pm \quad 0.8$ & $1.7 \pm 0.5$ \\
\hline Dead branches & $6300 \pm 1700$ & $12 \pm 3$ & $0.6 \pm 0.2$ & $1 \pm 0.4$ & $5 \pm 1$ & $0.6 \pm 0.2$ \\
\hline Stem wood & $93000 \pm 24000$ & $34 \pm 9$ & $6.5 \pm 1.7$ & $24 \pm 8$ & $93 \pm 24$ & $13.9 \pm 3.6$ \\
\hline Stem bark & $14200 \pm 3600$ & $28 \pm 7$ & $2.6 \pm 0.6$ & $12 \pm 3$ & $126 \pm 32$ & $4.1 \pm 1.0$ \\
\hline Tree total & $185000 \pm 47000$ & $256 \pm 63$ & $21.3 \pm 5.5$ & $136 \pm 33$ & $410 \pm 103$ & $49.5 \pm 12.3$ \\
\hline
\end{tabular}


Table 4. Quantity of phytomass and nutrients removed from a 110-year-old black spruce forest by conventional (stems only), full-tree, and whole-tree harvesting.

\begin{tabular}{|c|c|c|c|c|c|c|}
\hline \multirow{2}{*}{$\begin{array}{l}\text { Harvesting } \\
\text { method }\end{array}$} & \multirow{2}{*}{$\begin{array}{l}\text { Phytomass } \\
\left(\mathrm{kg} \mathrm{ha}^{-1}\right)\end{array}$} & \multicolumn{5}{|c|}{ Stand content ( $\mathrm{kg} \mathrm{ha}^{-1}$ ) } \\
\hline & & $\mathbf{N}$ & $\mathbf{P}$ & $\mathbf{K}$ & $\mathrm{Ca}$ & $\mathrm{Mg}$ \\
\hline Conventional & 107000 & 62 & 9 & 36 & 219 & 18 \\
\hline Full-tree & 142000 & 234 & 18 & 122 & 334 & 43 \\
\hline Whole-tree & 153000 & 239 & 19 & 125 & 353 & 45 \\
\hline
\end{tabular}

Table 5. Acidification (keq ha ${ }^{-1}$ ) associated with harvesting 110year-old black spruce.

\begin{tabular}{cccc}
\hline & $\begin{array}{c}\text { Conventional } \\
\text { harvest }\end{array}$ & $\begin{array}{c}\text { Full-tree } \\
\text { harvest }\end{array}$ & $\begin{array}{c}\text { Whole-tree } \\
\text { harvest }\end{array}$ \\
\cline { 2 - 4 } Cations & 18.5 & 40.8 & 47.8 \\
Anions & 1.1 & 2.8 & 3.2 \\
\hline Difference & 17.4 & 38.0 & 44.6 \\
\hline
\end{tabular}

available when the present stand originated after fire. Jeglum (1983) reported that after strip-cutting the proportion of trembling aspen and white birch in natural regeneration on similar sites increased relative to their abundance in the uncut forest. Hendrickson et al. (1987) have speculated that aspen, which accumulates large amounts of nutrients in foliage and bark, may take advantage of the increased availability of nutrients after harvesting. In a mature forest dominated by spruce and fir, white birch responded to added N, but black spruce did not (Morrison and Foster 1979). During early stand development, competition for nutrients between species is intense since the site must provide nutrients that in mature individuals could be translocated from older tissue into young tissues.

Forest removal, moreover, has an undesirable acidifying effect on the soil, because $\mathrm{K}, \mathrm{Ca}$ and $\mathrm{Mg}$ contained in the phytomass are not returned to the soil. The neutralizing effect of full incorporation of forest phytomass into the soil would be equivalent to $13 \%$ of the exchangeable acidity ( $335 \mathrm{keq} \mathrm{ha}^{-1}$ ) within the soil (effective rooting zone). This particular forest is remote from point sources of air pollution, with a 1979-1981 average annual $\mathrm{pH}$ of bulk precipitation of $5.4^{2}$. The annual acidifying effect of the vegetation removal by full-tree harvesting averaged over the rotation period was eight times greater than the estimated annual acid deposition from precipitation. Conventional harvesting would acidify the soil less than full-tree logging because less phytomass and hence less nutrients are removed.

There were sufficient nutrient reserves in the soil to replace the projected nutrient drain associated with another 100 -year rotation of spruce if conventional harvesting were conducted. Calcium and $\mathrm{K}$ removals by full-tree harvesting would exceed the reserves of extractable $\mathrm{Ca}$ and $\mathrm{K}$ in the soil, $\mathrm{P}$ and $\mathrm{Mg}$ removals would not (Tables 4,6). As Weetman and Webber (1972) have pointed out, however, exchangeable nutrient reserves are not necessarily those nutrients that are available to the vegetation. Exchangeable reserves are dynamic, changing in response to the release of nutrients from the much larger content associated with primary minerals in the soil. The size of the exchangeable pools is dependent on the rate of biological and geochemical reactions in the soil and on nutrients received from atmospheric sources.

\section{Nutrient Replenishment}

\section{Precipitation and Weathering}

Replenishment consists of nutrient inputs to the ecosystem (mineral weathering, precipitation) and the mineralization of organically combined nutrients to inorganic forms available to plants. Established forests can depend on nutrient cycling through decomposition of tree litter that helps satisfy their nutrient demands. Only a small portion of the nutrients absorbed annually by the forest is retained in the standing phytomass. Most are returned to the soil each year by litterfall. In this black spruce forest, a three-year average estimate of annual litterfall was $2600 \mathrm{~kg} \mathrm{ha}^{-1}$ of organic matter containing $15.0 \mathrm{~N} .1 .4 \mathrm{P}, 2.7 \mathrm{~K}, 15.5$. Ca, and $1.8 \mathrm{~kg} \mathrm{ha}^{-1}$ of $\mathrm{Mg}$.

Nutrients removed in harvesting can be replaced if atmospheric and weathering inputs exceed the nutrient loss associated with harvesting and leaching from the soil. Average (1980-1984) annual nutrient inputs in precipitation were approximately $7 \mathrm{~kg} \mathrm{ha}^{-1} \mathrm{~N}$ and $\mathrm{Ca}, 2 \mathrm{~K}, 1 \mathrm{Mg}$ and $0.5 \mathrm{P} 3$. Primary mineral weathering inputs averaged over a rotation were approximately $28 \mathrm{~kg} \mathrm{ha}^{-1} \mathrm{yr}^{-1}$ of $\mathrm{Ca}, 9$ of $\mathrm{Mg}$ and 2.5 of K. Weathering inputs were computed by difference with a mass balance equation in which the nutrient released is equal to leaching loss minus precipitation input plus change in storage in vegetation. Weathering and precipitation inputs together are greater than an annual prorated, projected nutrient loss that is due to full-tree harvesting, and this suggests that nutrient losses are replaceable.

Table 6. Distribution of organic matter and nutrients in a 110-year-old black spruce ecosystem.

\begin{tabular}{|c|c|c|c|c|c|c|}
\hline \multirow[b]{2}{*}{$\begin{array}{l}\text { Ecosystem } \\
\text { component }\end{array}$} & \multicolumn{6}{|c|}{ Nutrient distribution ( $\mathrm{kg} \mathrm{ha}^{-1}$ ) } \\
\hline & $\begin{array}{c}\text { Organic matter } \\
\left(\mathrm{kg} \mathrm{ha}^{-1}\right)\end{array}$ & $\mathbf{N}$ & $\mathbf{P}$ & $\mathbf{K}$ & $\mathbf{C a}$ & Mg \\
\hline Trees & 185000 & 256 & 21 & 136 & 410 & 50 \\
\hline Ground vegetation & 300 & 2.7 & 0.2 & 1.5 & 1.9 & 0.8 \\
\hline Moss & 1600 & 15.9 & 1.6 & 5.8 & 6.6 & 1.3 \\
\hline Forest floor & 120000 & 1790 & 100 & $75^{\mathrm{a}}$ & $206^{a}$ & $36^{a}$ \\
\hline Basal till & 11500 & 349 & 319 & $10^{\mathrm{a}}$ & $70^{\mathrm{a}}$ & $20^{a}$ \\
\hline Total & 463000 & 3660 & 777 & 257 & 792 & 142 \\
\hline
\end{tabular}

abased on exchangeable $\left(\mathrm{NH}_{4} \mathrm{OAc}-\mathrm{pH} 7\right)$ in forest floor and till 


\section{Nitrogen Cycling}

Nitrogen is the nutrient most limiting to the growth of conifers in the Canadian boreal forest (e.g., Weetman and Webber 1972, Foster and Morrison 1983). In mature boreal coniferous forests, the cycle of $\mathrm{N}$ from litterfall through the soil to the vegetation is commonly interrupted by $\mathrm{N}$ accumulation in humus ( $\mathrm{F}$ and $\mathrm{H}$ horizons) (Weetman and Webber 1972), brought on in part by $\mathrm{N}$ immobilization in microbial biomass during the decomposition process. It is difficult to generalize about the impact of $\mathrm{N}$ removals without examining the transformations of $\mathrm{N}$ in this soil in greater detail.

The total potential $\mathrm{N}$ mineralization, largely as $\mathrm{NH}_{4}^{+}-\mathrm{N}$, in the forest floor we examined was $40 \mathrm{~kg} \mathrm{ha}^{-1}$ over 12 weeks or approximately $2 \%$ of the total $\mathrm{N}$ in the forest floor. Our results contrast with those of Roberge and Knowles (1966) who reported no net mineralization of $\mathrm{N}$ in the humus layers of an upland black spruce forest. This suggests that there are large differences in $\mathrm{N}$ turnover rates in undisturbed black spruce forests. Actual mineralization rates are unlikely to approach potential rates, however, because optimum conditions for microbial activity are seldom maintained in the field. We suggest, therefore, that it is the slow rates of decomposition, rather than withdrawal of available $\mathrm{N}$ in microbial biomass, that are likely to limit $N$ release in this humus ( $F$ and $H$ horizons). Forest growth was not stimulated appreciably when additional $\mathrm{N}$ was applied to a nearby mature black spruce forest on a lower topographic position (Foster et al. 1986). Lack of response suggests that, on similar sites, the annual $\mathrm{N}$ turnover in the soil is sufficient to meet the $\mathrm{N}$ requirements of mature black spruce forest.

Mineralization of forest floor $\mathrm{N}$ reserves is likely to increase temporarily in the post-harvest period because of more favorable temperature conditions in the humus (Foster, unpubl.). On some sites the presence of nutrient-rich slash and litter after conventional harvest stimulates $\mathrm{N}$ transformations (nitrification, denitrification) that can reduce the $\mathrm{N}$ availability on the site. Potential nitrification ( $\mathrm{NO}_{2}^{-}$included) in the black spruce humus we examined was low in relation to $\mathrm{NH}_{4}^{+}-\mathrm{N}$ mineralization, in agreement with the findings of Roberge and Knowles (1966) and Mahendrappa and Salonius (1982). Nitrate-N, likewise, was a minor component $(0.2 \mathrm{~kg}$ $\mathrm{ha}^{-1} \mathrm{yr}^{-1}$ ) of $\mathrm{N}$ exports $\left(2.4 \mathrm{~kg} \mathrm{ha}^{-1} \mathrm{yr}^{-1}\right)$ from this forest in streamwater. ${ }^{4}$ Assessment of post-harvest nutrient losses from the land to streamwater will be presented in a companion paper (Nicholson, in preparation). Additional $\mathrm{N}$ losses by leaching and gaseous transfer in the post-harvest period are likely to be small. Phytomass removal from the site, therefore, is a good indication of the expected total $\mathrm{N}$ loss associated with harvesting. The consequences of $\mathrm{N}$ removal, even with full-tree harvesting, may not be severe since removals are modest in relation to total soil $\mathrm{N}$ reserves and their potential turnover on this site.

Weetman and Webber's (1972) contention that nutrient losses associated with full-tree harvesting of black spruce forest are unlikely to result in any additional nutrient limitations developing in acid tills of the Canadian Shield during a second rotation is supported by our results, despite the restricted rooting depth and volume on the site we examined. Weetman and Webber (1972), Gordon (1983) and Timmer et al. (1983) have cautioned that some infertile or shallow soils may contain insufficient $\mathrm{P}, \mathrm{K}$ or $\mathrm{Ca}$ to sustain a fully productive second rotation forest after full-tree logging. These studies

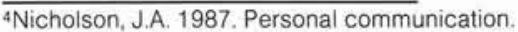

document the large site-to-site variability in nutrient reserves, as was observed in stand nutrient contents. For example, soil $\mathrm{Ca}$ reserves within the effective rooting zone on acid tills varied from $44 \mathrm{~kg} \mathrm{ha}^{-1}$ (Weetman and Webber 1972) to 2324 (Timmer et al. 1983). This, together with the high degree of uncertainty is quantifying site nutrient reserves, demonstrates the difficulties of trying to generalize about potential impacts of harvesting on the nutrition of future rotations of spruce forest. A modelling approach, perhaps one that develops and incorporates easy-to-quantify surrogates that might represent the nutrient status of a site, is needed to assess, on a site-bysite basis, the significance of nutrient losses owing to harvesting.

In summary, potential nutrient removals associated with full-tree harvesting were much greater than those associated with conventional (stems only) logging. There appear to be sufficient nutrient reserves and replenishment at this site after full-tree logging, despite the restricted rooting depth and volume, to sustain the next generation of spruce through the early growth period. Thereafter, nutrient drain on the soil reserves will be reduced by the extent that nutrient needs are met by nutrient cycling within the tree and the stand. These conclusions are based on the assumption that soil nutrient reserves will be protected from leaching and erosion by rapid revegetation. They should be substantiated by examining black spruce productivity and nutrient contents, at this site, during the next rotation. Nutrients contained in slash and forest floor horizons should be conserved because a substantial proportion of the nutrient reserves of a site are contained in these materials.

\section{Acknowledgments}

The assistance of Messrs. D. Kurylo and D. Ropke with sample collection, of Mr. J. Ramakers with chemical analysis of samples, and of Messrs. P. Hazlett and D. Ropke with analysis of the data is gratefully acknowledged. The cooperation of Domtar Inc. and the Ontario Ministry of Natural Resources, Nipigon District is appreciated.

\section{References}

Canadian Soil Survey Committee. 1978. The Canadian system of soil classification. Can. Dep. Agric., Ottawa, Ont. Publ. 1646. $164 \mathrm{p}$.

Foster, N.W. and I.K. Morrison. 1983. Soil fertility, fertilization and growth of Canadian forests. Dep. Environ., Can. For. Serv., Sault Ste. Marie, Ont. Report O-X-353. 21 p.

Foster, N.W., I.K. Morrison, and H.S.D. Swan. 1986. Growth response of a boreal black spruce stand to fertilizer treatments. North. J. Appl. For. 3: 142-144.

Freedman, B. and P.N. Duinker. 1985. Forest biomass and nutrient studies in central Nova Scotia. Part 5. Effects of potential nutrient removals with intensively harvested biomass on continued site productivity. Dalhousie Univ., Dep. Biol. Report to Can. For. Serv., ENFOR Program.

Gordon, A.G. 1983. Nutrient cycling dynamics in differing spruce and mixedwood ecosystems in Ontario and the effects of nutrient removals through harvesting. p. 97-118 in R.W. Wein, R.R. Riewe and I.R. Methven, Ed. Resources and Dynamics of the Boreal Zone. Assoc. Can. Univ. North. Stud.

Hegyi, F. 1972. Dry matter distribution in jack pine stands in northern Ontario. For. Chron. 48: 193-197.

Hendrickson, O.Q., D.M. Burgess and L. Chatarpaul. 1987. Biomass and nutrients in Great Lakes-St. Lawrence forest species: implications for whole-tree and conventional harvest. Can. J. For. Res. 17: 210-218.

Jeglum, J.K. 1980. Strip cutting in shallow-soil upland black spruce near Nipigon, Ontario. I. Study establishment and site conditions. Dep. Environ., Can. For. Serv., Sault Ste. Marie, Ont. Report O-X-315. $61 \mathrm{p}$.

Jeglum, J.K. 1983. Changes in tree species composition in naturally regenerating strip clearcuts in shallow-soil upland black 
spruce. p. 180-193 in R.R. Wein, R.R. Riewe, and I.R. Methven $E d$. Resources and Dynamics of the Boreal Zone. Assoc. Can. Univ. North. Stud.

Mahendrappa, M.K. and P.O. Salonius. 1982. Nutrient dynamics and growth response in a fertilized black spruce stand. Soil Sci. Soc. Am. J. 46: 127-133.

Morrison, I.K. 1985. Effect of crown position on foliar concentrations of 11 elements in Acer saccharum and Betula alleghaniensis trees on a till soil. Can. J. For. Res. 15: 179-183.

Morrison, I.K. and N.W. Foster. 1979. Five-year growth in two nitrogen-phosphorus fertilization experiments in spruce and spruce-fir upland forest in the Black Sturgeon Lake area of northern Ontario. Dep. Environ., Can. For. Serv., Sault Ste. Marie, Ont. Report O-X-299. 15 pp.

Roberge, M.R. and R. Knowles. 1966. Ureolysis, immobilization and nitrification in black spruce (Picea mariana Mill.) humus. Soil Sci. Soc. Am. Proc. 300: 201-204.
Rowe, J.S. 1972. Forest regions of Canada. Dep. Environ., Can. For. Serv., Ottawa, Ont. Publ. 1300. 172 p.

Timmer, V.R., H.M. Savinsky and G.T. Marek. 1983. Impact of intensive harvesting on nutrient budgets of boreal forest stands. p. 131-147 in R.W. Wein, R.R. Riewe, and I.R. Methven, Ed. Resources and Dynamics of the Boreal Zone. Assoc. Can. Univ. North Stud.

Van Cleve, K., L. Oliver, R. Schlentner, L.A. Viereck and C.T. Dyrness. 1983. Productivity and nutrient cycling in taiga forest ecosystems. Can. J. For. Res. 13: 747-766.

Weetman, G.F. and B. Webber. 1972. The influence of wood harvesting on the nutrient status of two spruce stands. Can. J. For. Res. 2: 351-369.

\section{Membership Dues 1987-1988}

\section{National Dues}

\section{Active Membership}

1 st and 2 nd year after graduation grad 1987, grad 1986)

Other new Active Members 1st year

Married or equivalent, second member only

All other Active Members

\section{Affiliate Membership}

1 st and 2 nd year after graduation

(grad 1987, grad 1986)

Other new Affiliate Members 1st year

Married or equivalent, second member only

All other Affiliate Members

Members with Retired Status receiving

The Forestry Chronicle

Members with Retired Status not receiving

The Forestry Chronicle

Student Members

Sustaining Members (CIF)

Sustaining Members (Other)
$\$ 67.00$

$\$ 67.00$

$\$ 67.00$

$\$ 94.00$

67.00

$\$ 67.00$

$\$ 67.00$

$\$ 88.00$

$\$ 29.00$

$\$ 00.00$

$\$ 27.00$

$\$ 30.00$

$\$ 200.00$

\section{Section Dues}

NS $\$ 5.00$

OK $\$ 5.00$

OR $\$ 5.00$

$\mathrm{CH} \$ 8.00$

OV $\$ 8.00$

CO $\$ 10.00$

PA $\$ 8.00$

CR $\$ 8.00$

RM $\$ 10.00$

KO $\$ 10.00$

SK $\$ 10.00$

SN $\$ 8.00$

SO $\$ 10.00$

LW $\$ 13.00$

MB $\$ 7.00$

MR $\$ 18.00$

VA $\$ 10.00$

ND $\$ 10.00$

VI $\$ 5.00$

NO $\$ 5.00$

NW $\$ 10.00$

The Institute year runs from July 1 to June 30. Applications dated after January 1 will be charged half dues for that Institute year. Applications dated after April 1 will be charged no dues for that Institute year.

Section dues are in addition and range from $\$ 5.00$ to $\$ 18.00$. 